\section{Phenomenological Interpretations of Ancient Philosophy}

Editors: Kristian Larsen and Pål Rykkja Gilbert

Ancient philosophy has from the outset inspired phenomenological philosophers in a special way.

Phenomenological Interpretations of Ancient Philosophy offers fresh perspectives on the manner in which ancient Greek thought has influenced phenomenology and traces the history of this reception. Unlike various related treatments, the present volume offers a broad account of this topic that includes chapters on Edmund Husserl, Martin Heidegger, Hans-Georg Gadamer, Jacob Klein, Hannah Arendt, Eugen Fink, Jan Patočka, Emmanuel Levinas, and Jacques Derrida.

This collection of essays, edited by Kristian Larsen and Pål Rykkja Gilbert, is addressed to students of ancient philosophy and the phenomenological tradition as well as to readers who have a general interest in the fascinating, yet complex, connection between ancient Greek thought and phenomenological philosophy.

Contributions by: Jussi Backman, Pål Rykkja Gilbert, Burt Hopkins, Filip Karfík, Alexander Kozin, Kristian Larsen, Arnaud Macé, Claudio Majolino, Hans Ruin, Thomas Schwarz Wentzer, Vigdis Songe-Møller, Tanja Staehler, Morten S. Thaning and Charlotta Weigelt.

Readership

Scholars and students interested in phenomenology, ancient philosophy, and the way ancient philosophy has influenced the thought of various phenomenological thinkers such as Husserl, Heidegger, Arendt, and Derrida.

For more information see brill.com
Phenomenological

Interpretations

of Ancient

Philosophy

Edited by

Kristian Larsen

and Pål Rykkja Gilbert

Language: English

Subjects: 19th \& 2oth Century

Philosophy, Philosophy, Ancient

Philosophy, Philosophy,

Epistemology \& Metaphysics,

Philosophy, Continental

Philosophy, Philosophy

Publisher: Brill

Series:

Studies in Contemporary

Phenomenology, Volume: 20

E-Book (PDF)

Publication Date: 17 Jun 2021

ISBN: 978-90-04-44677-9

List price

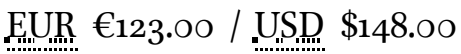

Hardback

Publication Date: 17 Jun 2021

ISBN: 978-90-04-44676-2

List price

EUR $€ 123.00 /$ USD $\$ 148.00$ 
Order information: Order online at brill.com

The Americas: 1 (860) 350 o041 | brillna@turpin-distribution.com

Outside the Americas: 44 (o) 1767 604-954 | brill@turpin-distribution.com Submission information: brill.com/authors

Titles published by Ferdinand Schöningh, Wilhelm Fink and mentis: +49 (o)71541327 10 | brill@brocom.de 